\title{
Induction of IFNa or IL-12 depends on differentiation of THP-1 cells in dengue infections without and with antibody enhancement
}

\author{
Rong-Fu Chen ${ }^{1}$, Lin Wang ${ }^{2}$, Jiin-Tsuey Cheng ${ }^{3}$ and Kuender D Yang ${ }^{1 *}$
}

\begin{abstract}
Background: Appropriate induction of the early Th1 cytokine IL-12 is a critical defense directed against viral infection. We have previously shown that different viruses elicited either IL-12 or IFNa dependent Th1 reactions. Using dengue-2 virus, we sought to explore how dengue-2 induced IL-12 or IFNa expression by monocytic and its derived dendritic cells.

Methods: We employed human monocytic cell line, THP-1, to investigate whether differentiation of monocytic cells is involved in the switch between IFNa and IL-12 induction. Flow cytometry, RT-PCR and ELISA were respectively used to determine cell differentiation, IL-12 and IFNa mRNA expression and protein production.

Results: THP-1, expressing CD123, which is a plasmacytoid dendritic cell marker, but not CD14, CD11b or CD11C revealed IFNa mRNA expression while stimulated by dengue-2. In contrast, PMA-induced THP-1 differentiation toward monocytic cells expressed CD11 $\mathrm{b}^{+}$, and $\mathrm{CD} 14^{+}$, but not CD123, and revealed exclusively IL-12 expression while stimulated by dengue-2. Further studies showed that $\mathrm{CD}_{123^{+}}$expressing THP-1 cells elicited higher IFNa expression in dose and time dependent induction after infection, and PMA-induced monocytic differentiation of THP-1 cells revealed IL-12 expression. Antibody-dependent enhancement of DEN-2 infection significantly suppressed the DEN-2 induced IL-12 p40 expression in monocytic differentiated THP-1 cells.
\end{abstract}

Conclusions: Clarification and modulation of the early Th1 reaction in different monocytic cells may change or prevent complication from dengue infection.

Keywords: Monocyte, Deneritic cells, Differentiation, CD123, IFNa, IL-12

\section{Background}

Dengue fever (DF) is transmitted by mosquitoe bite which introduces dengue viruses (DEN) including 4 serotypes. DF is highly prevalent in tropical and subtropical areas, with at least 50 million new cases each year $[1,2]$. Occasional, DF progresses to dengue hemorrhagic fever (DHF), a potentially life threatening complication associated with vascular leakage, hemorrhage, thrombocytopenia and shock [3-5]. More than 1 billion people are at risk of dengue infection and there are approximately 100 million cases of DF and 500,000 cases of DHF every year [6]. DHF has been classified into four

\footnotetext{
* Correspondence: yangkd.yeh@hotmail.com

'Department of Medical Research and Development, Show Chwan Health Care System, Changhua, Taiwan

Full list of author information is available at the end of the article
}

grades on the basis of clinical presentation. The mildest is grade I and the most severe is grade IV [7,8]. The first indication of an immunological mechanism for DHF was the observation in a Bangkok outbreak of DHF in 1960s [9]. In that outbreak, over $85 \%$ of children with DHF had high DEN heterotypic cross-reactive antibody titers, suggesting an antibody-dependent enhancement (ADE) of DEN infection in the pathogenesis [10]. Monocytes, macrophages and dendritic cells (DCs) play a crucial role in immune responses against virus infection, in which IL-12 and IFN $\alpha / \beta$ are early mediators of Th1 cell immunity [11-13]. It is well known that IL-12 derived from monocytes or dendritic cells can polarize Th1 reaction [14-16]. Whether type I interferons are involved in IFN $\gamma$ induction mediating Th1 reaction remains controversial $[17,18]$. Recently, we have found that different microorganisms

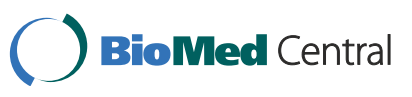


could induce IL-12 or IFN $\alpha$ to polarize Th1 reaction in a mutually exclusive fashion [16]. Different viruses induce IL-12 or IFN $\alpha$ mutually exclusive is usually mediated via ligation of different toll-like receptors (TLRs) [19-21].

$\mathrm{DCs}$ play a central role in the initiation of $\mathrm{T}$ cellmediated antiviral immune responses [22,23]. Different DCs release different cytokines to polarize $\mathrm{T}$ helper (Th) cells. Plasmacytoid DCs release IFN $\alpha / \beta$ to polarize Th1 reaction [24], myeloid DCs release mainly IL-12 to enhance Th1 reaction [25], and regulatory DCs release IL10 or TGF $\beta$ to polarize Treg [26]. Besides, DCs are very effective at taking up antigen, by pinocytosis of soluble compounds, macropinocytosis of high-molecular-weight antigens and phagocytosis of particles [27]. After encountering antigen, DCs migrate to the lymph nodes where DCs activate specific $\mathrm{T}$ cells [28]. The migration is dependent on the expression of chemokine receptors, which enable the cells to sense chemotactic gradients, and cell adhesion molecules for interaction with endothelial cells. Several of these molecules play important regulatory roles, such as ALCAM, which is expressed on activated $T$ cells and on monocyte-derived DCs, and might play a role in DC migration [29].

We have previously shown that DHF, a potential fatal complication of DF, is associated with higher Th2 reaction [30-32] and lower Th1 polarization [33]. Moreover, we have also demonstrated that varicella-zoster virus and Bacillus Calmette-Guerin (BCG) induce IFN $\alpha$ and IL-12 production, respectively [16]. This study was conducted to investigate whether differentiation of monocytic cells is involved in the switch between IFNa and IL-12 induction after dengue infection, and whether ADE of dengue infection could modulate the production of IFN $\alpha$ and IL-12 by different monocytic cells.

Monocytes and macrophages are recruited to sites of inflammation and play critical roles in innate host defense mechanisms. THP-1, human promonocytic leukemia cells, grow as nonadherent promonocytes, and differentiate to macrophage-like cells upon treatment with PMA [34,35]. PMA, a potent activator of PKC, arrests THP-1 proliferation and induces the expression of several macrophage characteristics [36-38]. It remains unclear whether THP-1 monocytic cells can express IFN $\alpha$ or IL-12, depending on differentiation; or THP-1 monocytic can develop into different DCs, responsible for exclusive IFN $\alpha$ or IL-12 expression. ADE of dengue has long been implicated in severe, usually secondary, DEN infections. Preexisting heterotypic antibodies of dengue might promote dengue infection via their Fcgamma receptor $(\mathrm{Fc} \gamma \mathrm{R})$ [39], this may not only facilitate the virus' entry, but also modifies innate and adaptive immune responses [40]. Employing DEN-2 virus, which is known to cause the most outbreaks of DHF, associated with altered Th1/Th2 reaction [41-45], we attempted to explore DEN-2 virus induction of IFN $\alpha$ or IL-12 in a monocytic differentiation model.

\section{Methods}

\section{Reagents and medium}

Phorbol 12-myristate 13-acetate (PMA), and dimethyl sulfoxide (DMSO) were purchased from Sigma Chemical Co. (St. Louis, MO). RPMI 1640 culture medium was obtained from Gibco BRL (Grand Island, NY, USA). Fetal bovine serum (FBS), gentamicin, and L-glutamine were purchased from Gibco BRL, Inc. (Grand Island, N.Y., USA).

\section{Cells culture}

Monocytic THP-1 cells were grown in RPMI 1640, 10\% FBS (endotoxin level $<0.25 \mathrm{EU} / \mathrm{mL}$; Gibco BRL, Grand Island, N.Y., USA), $2 \mathrm{~m} M$ L-glutamine (Gibco BRL, Grand Island, N.Y., USA) at $37^{\circ} \mathrm{C}$, and $5 \% \mathrm{CO}_{2}$ incubator. THP- 1 cells $\left(2 \times 10^{5}\right.$ cells $\left./ \mathrm{ml}\right)$ were subcultured every 3 days, and PMA ( $8 \mathrm{nM}$ ) was used to induce THP-1 cell differentiation. To study time dependent effect, cells $\left(2 \times 10^{6}\right.$ cells $\left./ \mathrm{ml}\right)$ were used for studies with dengue- 2 infection at multiplicity of infection (MOI) $=1.0$ for 6 to 72 hours as indicated. For studying different infection dose, we used MOI from 0.1, 0.5, 1, 5 and 10 to study its dose-dependent effect.

\section{Dengue-2 virus preparation}

Dengue virus type 2 (DEN-2, New Guinea C strain, ATCC) was obtained from the Institute of Preventive Medicine, National Defense Medical Center, Taipei. Viruses were propagated in C6/36 mosquito cells in Eagle's minimal essential medium (MEM) (Gibco BRL, Grand Island, N.Y., USA) containing nonessential amino acids (Gibco BRL, Grand Island, N.Y., USA), 1\% sodium pyruvate, $0.2 \%$ sodium bicarbonate and supplemented with 1\% antibiotic (Gibco BRL, Grand Island, N.Y., USA) and $10 \%$ heat-inactivated $\mathrm{FBS}$ at $28^{\circ} \mathrm{C}$ for 5 days. Baby hamster kidney cells (BHK-21) were grown in MEM as described above. A large collection of virus culture was pooled and showed a titer of $1.0 \times 10^{7} \mathrm{PFU} / \mathrm{ml}$ determined by real-time quantitative RT-PCR as previously described [30]. All experiments about DEN infection were set at $\mathrm{MOI}=1$.

\section{Flow cytometric analyses of cell surface markers}

In order to characterize the change of cell differentiation markers on THP-1 cells, we measured pDC-specific and $\mathrm{mDC}$-specific markers on THP-1 cells by flow cytometry. These cells $\left(2 \times 10^{6}\right.$ cells $\left./ \mathrm{ml}\right)$ are treated with and without 8 nM PMA for 72 hours. Cell surface stainings were performed by direct immunofluorescent assay with fluorescence-conjugated mAbs (CD14-PE, CD11b-PE, 
CD11c-PE, and CD123-FITC) and corresponding isotype control antibodies for 30 minutes. After washing in PBS twice, cells were fixed in $2 \%$ paraformaldehyde for $20 \mathrm{~min}$, washed, and resuspended at $\sim 10^{6}$ cells per milliliter before acquisition.

\section{Real-time quantitative RT-PCR analysis of IL12B and IFNa mRNA expression}

We subjected total RNA extracted from THP-1 cells with and without differentiation treatment to quantitative analysis of mRNA expression of IL12B and IFNa. In brief, the cell pellet was mixed with $0.5 \mathrm{ml}$ of Tri-Zol solution (Invitrogen, California, USA). After thorough vortexing, samples were added $0.1 \mathrm{ml}$ of chloroform (Scharlau, sa, Barcelona, European Union) for phase separation. After centrifugation, the upper aqueous phase was transferred to a fresh DEPC-treated eppendorf and the same volume of isopropanol (Merck KGaA, Darmstadt, Germany) was added for RNA precipitation at $-20^{\circ} \mathrm{C}$ for 1 hour. The RNA was harvested by centrifugation at $12,000 \times \mathrm{g}$ for 10 minutes at $4^{\circ} \mathrm{C}$, followed by 75\% ethanol (Merck KGaA, Darmstadt, Germany) precipitation. Finally, the RNA was subjected to the realtime RT-PCR detection with SYBR Green PCR reagents (RealQ-PCR Master Mix Kit, Ampliqon) using the ABI PRISM 7500 instrument (Applied Biosystems, Foster City, CA) as previously described [46]. Primers for the quantitative detection of target mRNAs were designed by using Primer Express computer software (Applied Biosystem, Foster City, CA). For the IL12B gene, the primer sequences were 5'- acctccacctgccgagaat-3' (forward)

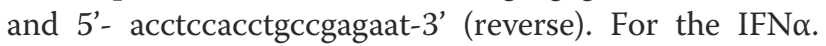
gene, the primer sequences were $5^{\prime}$-atttctgctctgacaacctc3' (forward) and 5'-tgacagagactcccctgatg-3' (reverse) [47]. In order to evaluate PCR efficiency, a 3 replicates and 5$\log$ dilution series were performed. A slope of $-3.3 \pm 10 \%$ reflects an efficiency of $100 \% \pm 10 \%$. Samples were analyzed in three independent duplicate experiments. The RT-PCR cycling parameters were set as follows: the RT reaction at $50^{\circ} \mathrm{C}, 2$ minutes; $60^{\circ} \mathrm{C}, 30$ minutes; and $95^{\circ} \mathrm{C}$, 5 minutes; followed by 40 cycles of PCR reactions at $94^{\circ} \mathrm{C}$, 20 seconds, and $60^{\circ} \mathrm{C}, 1$ minute. The results were detected in a real-time fashion and recorded on a plot showing fluorescence vs. time. RT-PCR products were also visualized on ethidium bromide-stained $1.5 \%$ agarose (Pierce Co., Rockford, IL, USA) gel with a 100-bp ladder (Pharmacia Biotech, Piscataway, NJ, USA) as a reference. The increase of the IL12B and IFN $\alpha$ mRNA expression were therefore calculated assuming 100\% efficient PCR where each $C_{t}$ was normalized to $\beta$-actin mRNA expression as shown by the equation at $2^{[\mathrm{Ct} 1 \text { (target) }-\mathrm{Ct} 1 \text { (actin)][Ct2(target)-Ct2(actin)] }}$. The $\mathrm{C}_{\mathrm{t}} 1$ (target) and $\mathrm{C}_{\mathrm{t}} 2$ (target) represent the $\mathrm{C}_{\mathrm{t}}$ values for the IL12B or IFN $\alpha$ gene expression in treated and mock samples, respectively. $C_{t} 1$ (actin) and $C_{t} 2$ (actin) represent the $C_{t}$ values for the $\beta$-actin gene.

\section{Measurement of IFNa, and IL-12 p40 levels}

To measure IL-12 protein production, $10^{6}$ THP- 1 cells with or without PMA treatment per well are seeded into 1-ml culture medium in triplicates in 24-well tissue-culture plates and incubated at $37^{\circ} \mathrm{C}$ in humidified $5 \% \mathrm{CO}_{2}$ atmosphere in the presence or absence of different stimuli, as indicated above. After 24 and 72 hours, cell-free culture supernatants are removed and assayed for multispecies IFN- $\alpha$ (PBL Biomedical Laboratories, Endogene Inc., Cambridge, MA, USA), IL-12 p40 (R\&D Systems, Minneapolis, MN, USA) concentrations using ELISA. The results were calculated from interpolation in a standard curve made from a series of well-known concentrations of commercial standards [30,32].

\section{Assessment of antibody-dependent enhancement of virus infections in differentiated THP-1 cells}

To assess ADE, DEN-2 viruses were preopsonized with and without DEN-1 or DEN-2 immune sera at $4^{\circ} \mathrm{C}$ for $60 \mathrm{~min}$ as previously described [32], PMA-differentiated THP- 1 cells $\left(2 \times 10^{5}\right.$ cells $\left./ \mathrm{ml}\right)$ were incubated with DEN2 virus with and without DEN immune sera at MOI of 1 at $37^{\circ} \mathrm{C}$ for $60 \mathrm{~min}$. The infected cells were washed to remove extracellular viruses before culture in RPMI 1640. The infected PMA-differentiated THP-1 cells were cultured for 24 hours before the culture supernatants were harvested for determination of DEN-2 virus titers by real-time RT-PCR assay for 40 cycles using TaqMan technology (Applied Biosystems, Foster City, CA). The forward primer, reverse primer and nested fluorescent probe sequence for detecting DEN-2 were 5'-GGC TTA GCG CTC ACA TCC A-3', 5'-GCT GGC CAC CCT CTC TTC TT-3', and FAM-CGC CCA CCA CTA TAG CTG CCG GA-TAMRA, respectively [30]. The intracellular viruses were harvested from the cell pellets after washing twice with PBS to remove extracellular virus. The cell pellets were frozen and thawed for three times to release intracellular DEN-2 virus, then resuspended to $20 \mu \mathrm{l}$ and subjected to real-time RT-PCR assay.

\section{Data and statistical analyses}

Data are presented as mean \pm SEM values. Mann Whiteney $U$ test was used to analyze IL12B and IFNa RNA expression levels between undifferentiated and differentiated THP-1 cells with and without DEN-2 infection. A $P$ value of $<0.05$ was considered statistically significant. All analyses were performed using SPSS 13.0 (SPSS Inc. Chicago, IL, USA). 


\section{Results}

Undifferentiated THP-1 expressing pDC markers released IFNa but not IL-12 after DEN-2 infection

In order to characterize the expression of cell markers on THP-1 cells, we assessed the CD123 levels, a pDCspecific marker, on THP-1 cells by flow cytometry. As shown in Figure 1A, CD123 was expressed on the surface of THP-1 and down-regulated on the PMAdifferentiated THP-1 cells. To investigate whether THP-1 cells elicited Th1 promoting cytokines under DEN-2 infection, cellular RNA was extracted and assessed using real-time RT-PCR after $24 \mathrm{~h}$ infection. Higher levels of IFN $\alpha$ mRNA but not IL12B mRNA were induced in post-infected THP-1 cells by DEN-2 (Figure 1B).

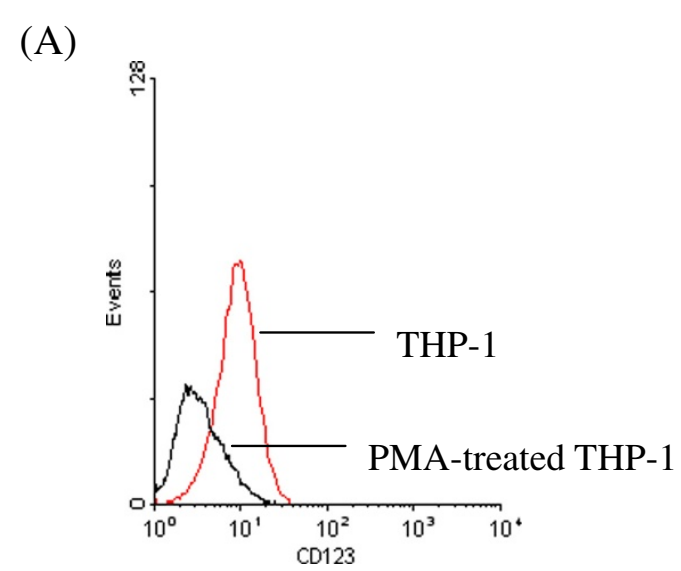

(B)

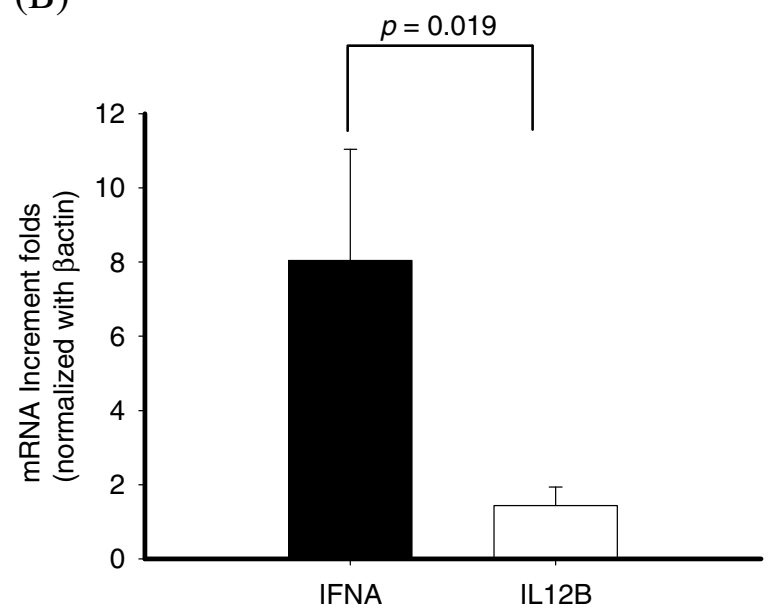

Figure 1 Flow cytometric analysis of CD123 expression in THP1 with or without PMA differentiation (A). Expression of IFNA and IL12B mRNA expression in THP-1 cells with DEN-2 infection (B). Six RNA samples from cells were subjected to testing IFNA ( $\mathbf{\square})$ and IL12B ( $\square$ ) mRNAs by SYBR Green real-time RT-PCR analysis. $(p=0.019)$
Differentiated THP-1 expressing mDC markers released IL12 but not IFNa after DEN-2 infection

THP-1 cells grew as a single-cell suspension, and only a few cells spread onto the flask substrate. Approximately $80 \%$ of the cells attached to the substrate as early as $3 \mathrm{~h}$ after the addition of PMA (8 nM). After a 72-h treatment with PMA, THP-1 spread onto the substrate to be irregular and flattened in shape. Addition of DMSO only at the same dilutions required for obtaining the given concentrations of PMA in culture system did not induce adherence of the cells to the substrate.

The effect of PMA treatment on the expression of surface markers of THP-1 cells was examined by flow cytometry. THP-1 treated with 8 nM PMA expressed more mDC cell markers such as CD14, CD11b, and CD11c (Figure 2A-C), but not CD123, pDC cell markers (Figure 1A). To analyze whether PMA-treated THP-1 cells elicited Th1 promoting cytokines under DEN-2 infection, cellular RNA was extracted and assessed using real-time RT-PCR after $24 \mathrm{~h}$ DEN-2 infection. Higher levels of IL12B mRNA but not IFN $\alpha$ mRNA were induced in PMA-treated THP-1 cells after 24 h DEN-2 infection (Figure 2D).

\section{Dose dependent and kinetic induction of IFNa /IL12B} mRNA in THP-1 cells with or without PMA differentiation after DEN-2 infection

Undifferentiated THP-1 cells elicited higher production of IFN $\alpha$ mRNA (Figure 1B); PMA-treated THP-1 cells after DEN-2 infection expressed IL12B mRNA (Figure 2D). To investigate whether Th1 promoting cytokines induced in undifferentiated THP-1 cells were dose dependent, cells were infected by different DEN-2 titers $(\mathrm{MOI}=0.1 \sim 5)$ and RNA were assessed by realtime RT-PCR. As shown in Figure 3A, THP-1 elicited IFN $\alpha$ mRNA levels when cells infected by DEN-2 even at lower MOI, and induced IFN $\alpha$ mRNA reached the maximum at $\mathrm{MOI}=5$. To analyze whether Th1 promoting cytokines were kinetically induced in THP-1, cells were infected by DEN-2 at MOI $=1$ at different time from $30 \mathrm{~min}, 1 \mathrm{~h}, 2 \mathrm{~h}, 6 \mathrm{~h}$, and $24 \mathrm{~h}$. Results showed that the IFN $\alpha$ mRNA expressing levels were kinetically increased in undifferentiated THP-1 cells and reached the maximum at $24 \mathrm{~h}$ post-infection of DEN-2 (Figure 3B). Interestingly, the IL12B mRNA expressing levels were also kinetically induced and dose-dependent in PMA-differentiated THP-1 cells and reached its maximum induction at $24 \mathrm{~h}$ post-infection of DEN-2 (Figure 3C, D). In order to understand whether the induction of Th1 promoting cytokines were limited to transcriptional level, we assessed the cytokine levels by ELISA in the same reactions. However, we could not detect the IFN $\alpha$ production in the supernatants of DEN-2 infected undifferentiated THP-1 cells. However, only 


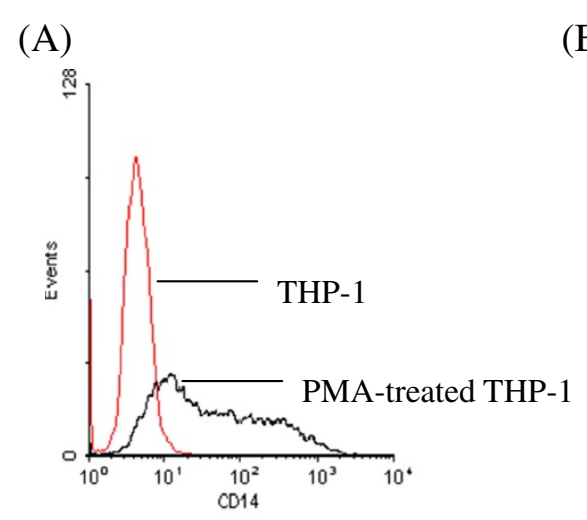

(B)

(C)

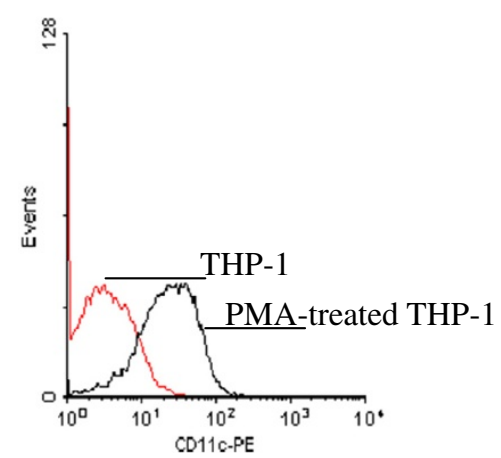

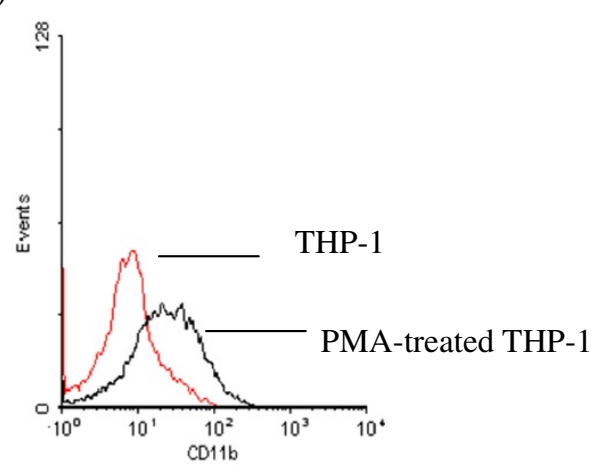

(D)

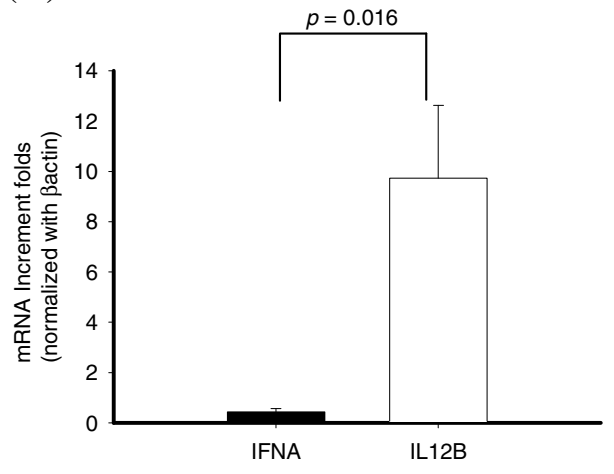

Figure 2 Flow cytometric analysis of CD14, CD11b, CD11c expression in THP-1 with or without PMA differentiation (A-C). Expression of IFNA and IL12B mRNA expression in PMA-treated THP-1 cells with DEN-2 infection (D). Six RNA samples from cells were subjected to testing IFNA $(\mathbf{m})$ and IL12B ( $\square)$ mRNAs by SYBR Green real-time RT-PCR analysis. $(p=0.016)$.

IL-12 p40 proteins were kinetically and dose-dependently detected in PMA differentiated THP-1 cells Results showed that IL-12 p40 production could be induced at $1 \mathrm{~h}$ post-infection of DEN-2 and also reached its maximum at $24 \mathrm{~h}$ post-infection of DEN-2 in differentiated THP-1 cells, but not in undifferentiated THP-1 cells (Figure 3E, F).

\section{Down-regulation of IL12B in antibody dependent} enhancement of DEN-2 infected differentiated THP-1 cells Antibody-dependent enhancement of DEN-2 infection occurred when sub-neutralizing antibodies facilitated DEN-2 infection via Fc receptors (FcR). To investigate the role of IL-12 p40 in ADE of DEN-2 infection, we compared the viral replication and IL12B expression in the differentiated THP-1 cell using real-time RT-PCR. As shown in Figure 4A, we found that the subneutralizing DEN-1 antiserum could enhance DEN-2 replication in differentiated THP-1 cells from $2.64 \times 10^{5}$ copies $/ \mathrm{ml}$ to $1.49 \times 10^{6}$ copies $/ \mathrm{ml}$ in the presence of antiserum at 1:1250 dilution. However, anti-DEN2 antiserum at 1:1250 dilution did not enhance DEN-2 replication in differentiated THP-1 cells $\left(2.64 \times 10^{5}\right.$ copies $/ \mathrm{ml}$ vs. $3.28 \times 10^{5}$ copies $/ \mathrm{ml}$ ). To measure the expression of IL12 p40 levels in the ADE of DEN-2 infection of differentiated THP-1 cells, we found that DEN-2 infection induced a higher IL12B expression (Figure 4B). Presence of anti-DEN1 antiserum at 1:1250 dilution, but not antiDEN2 antiserum, significantly suppressed the DEN-2 induced IL12B expression in differentiated THP-1 cells.

\section{Discussion}

Several prospective studies have concluded that DHF is more common in secondary DEN infections than in primary DEN infections $[9,48]$. Despite extensive studies, the pathogenesis of DHF cannot be fully attributed to the ADE. Activation of dengue virus-specific $\mathrm{T}$ cells and dengue virus-infected monocytes may result in increased capillary permeability in patients with DHF $[49,50]$. Recently, cytokines related to dominant Th2 reaction have been related to the pathogenesis of DHF $[44,48,51,52]$. We showed that increase of Th1 cytokine, IL12B expression in differentiated THP-1 cells was found in DEN-2 infection (Figure 3C, D). We also found that 
(A) Without PMA

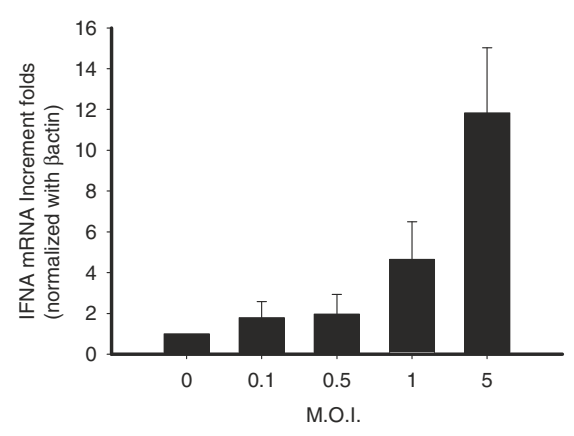

(C) With PMA

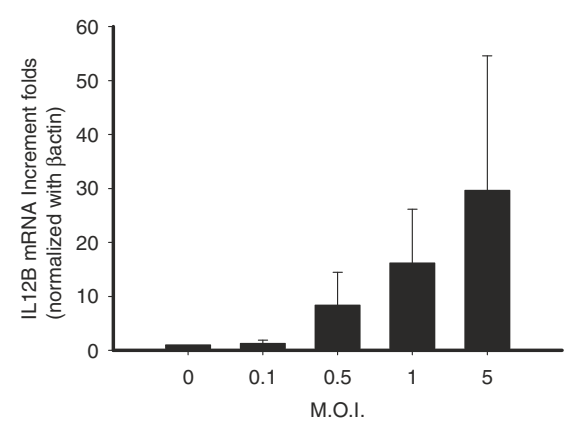

(E) With PMA

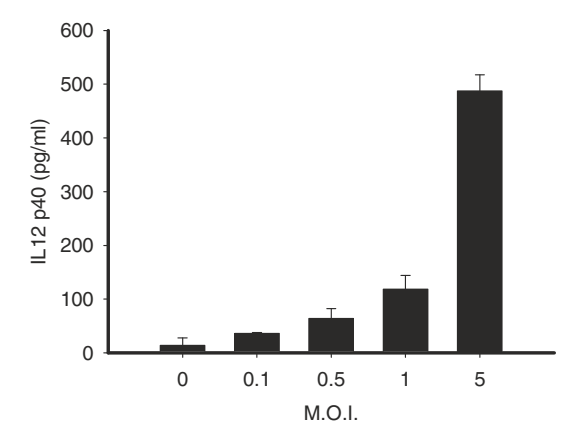

(B) Without PMA

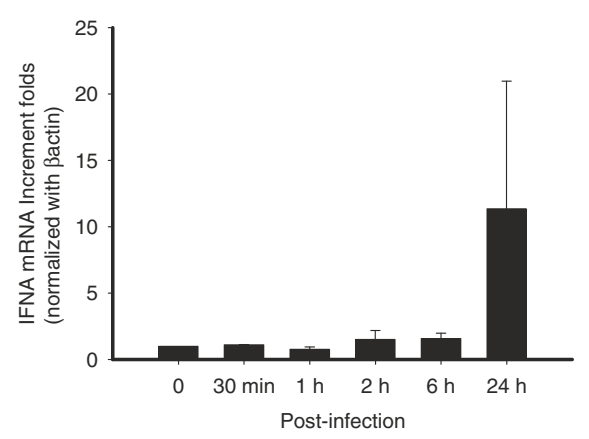

(D) With PMA

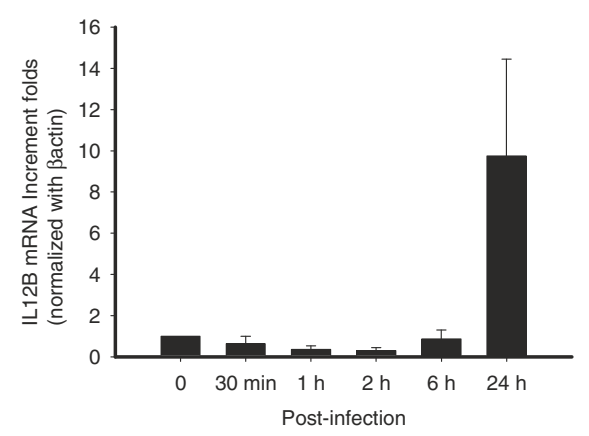

(F) With PMA

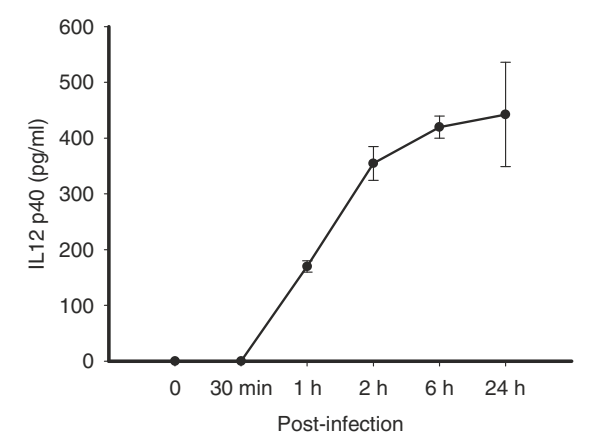

Figure 3 Dose-dependent and kinetic induction of IFNA and IL12B expression in DEN-2-infected THP-1 cells with or without PMA differentiation. A series of M.O.I. of DEN-2 were assessed at post-infection 24 h, RNA samples from THP-1 (A) or PMA-differentiated THP-1 (C) cells were subjected to testing IFNA and IL12B mRNAs by SYBR Green real-time RT-PCR analysis. A different post-infection time of DEN-2 were assessed at M.O.I.=1, RNA samples from THP-1 (B) or PMA-differentiated THP-1 (D) cells were subjected to testing IFNA and IL12B mRNAs by SYBR Green real-time RT-PCR analysis. The similar dose response (E) and kinetic induction (F) of IL-12 p40 proteins in the supernatants of DEN-2 infected PMA-differentiated THP-1 cells by ELISA in the same reactions.

heterotypic antibody mediated DEN-2 infection significantly enhanced DEN-2 replication, but suppressed the IL12B expression.

Distinct DC subsets are known to exhibit intrinsic differences in their ability to: 1 ) regulate the quality of the Th response (Th1, Th2, or cytotoxic $\mathrm{T}$ lymphocyte [CTL]); 2) produce antiviral type I IFNs; and 3) crosspresent exogenous Ags to $\mathrm{CD}^{+} \mathrm{T}$ cells [53]. Our results indicate that treatment of human monocytic leukemia cell line, THP-1, cells with 8 nM PMA for $72 \mathrm{~h}$ promotes a differentiation phenotype that is characterized by morphological changes and altered IFN $\alpha$ gene induction. The PMA could induce THP-1 cells to differentiate toward macrophage has been well demonstrated [54-56]. We however demonstrated an up-regulation in expression of $\mathrm{mDC}$-related molecules associated with monocyte differentiation, notably CD11b, CD11c and CD14. Concomitantly, the expression of CD123 was selectively downregulated in the PMA differentiated THP1 cells. Theses cell surface markers were partly similar to 


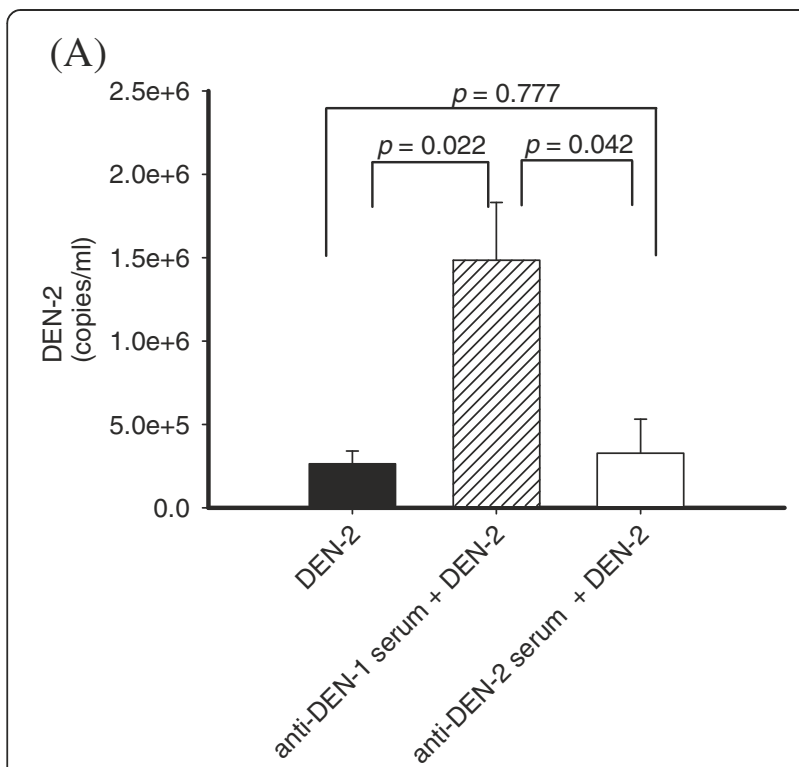

(B)

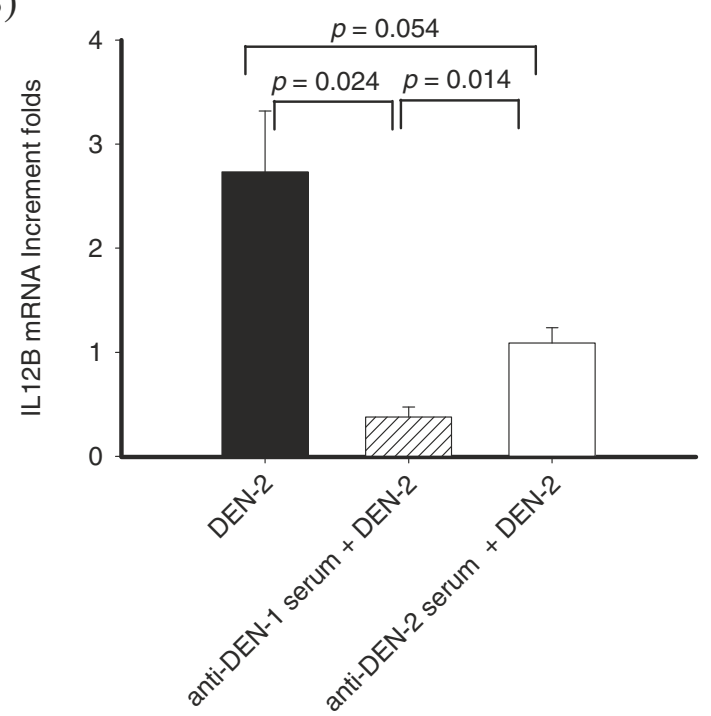

Figure 4 Enhanced DEN-2 replication but suppressed IL12B in heterotypic antibody-mediated DEN-2 infected differentiated THP-1 cells. (A) To compare viral replication, viral load of DEN-2 in antiserum-mediated DEN-2 infection was determined by TaqMan real-time RT-PCR (DEN-2 (घ), anti-DEN1 antiserum + DEN-2 (1), and anti-DEN2 antiserum + DEN-2 ( $\square), p=0.022,0.042$, and 0.777 respectively) after infection of DEN-2 for $24 \mathrm{~h}$ in a summary calculated from the results of 5-paired experiments. Suppression of IL12B levels in differentiated THP-1 cells was found in the addition of anti-DEN1 antiserum diluted to 1:1250 after infection of DEN-2 for $24 \mathrm{~h}$ (B) (DEN-2 (-), anti-DEN1 antiserum + DEN-2 (\%), and anti-DEN2 antiserum + DEN-2 ( $\square), p=0.024,0.014$, and 0.054 respectively) after infection of DEN-2 for $24 \mathrm{~h}$ in a summary calculated from the results of 5-paired experiments. the criteria of differences between myloid DCs and plasmacytoid DCs. THP-1 cells induced elevated IFNa mRNA expression under DEN-2 infection, however, PMA-differentiated THP-1 cells elicited higher IL12B mRNA expression and protein levels under the same infection. The induction of early Th1 cytokines was dose-dependent and time-dependent in THP-1 with or without PMA differentiated cells.

\section{Conclusion}

Human blood DCs can be divided into several distinct phenotypic and functional subpopulations, and both monocytes-derived DCs and PMA-differentiated THP-1 cells are of the myeloid $\mathrm{CD} 11 \mathrm{~b}^{+} \mathrm{CD} 11 \mathrm{c}^{+}$and $\mathrm{CD} 14^{+}$, resembling their in vivo myeloid counterpart [29]. We showed that THP-1, likes pDCs, responded to DEN-2 by secreting IFN $\alpha$; on the other hand, PMA-differentiated THP-1 cells, act as $\mathrm{mDC}$, responded to DEN-2 by secreting IL-12. This model may be a good model system for studying early innate immunity of virus infections, and provide a better strategy to prevent infection and complication.

\section{Abbreviation}

ADE: Antibody-dependent enhancement; ALCAM: Activated leukocyte cell adhesion molecule; DC: Dendritic cell; DF: Dengue fever; DHF: Dengue hemorrhagic fever; DMSO: Dimethyl sulfoxide; DSS: Dengue shock syndrome; FBS: Fetal bovine serum; FcyR: Fc-gamma receptors; mDC: Myeloid dendritic cells; pDC: Plasmacytoid dendritic cells; PMA: Phorbol 12-myristate 13acetate; RT-PCR: Reverse transcriptase-polymerase chain reaction; TLR: Tolllike receptor.

\section{Competing interests}

The authors have declared that no competing interest exists.

\section{Authors' contribution}

RF carried out the data collection, data interpretation and drafted the manuscript. $L$ carried out the immunoassays and performed the statistical analysis. JT participated in the design of the study. KD conceived of the study, and participated in its design and coordination and helped to draft the manuscript. All authors read and approved the final manuscript.

\section{Acknowledgements}

The authors have benefited from the statistical advice by Dr. Eng-Yen Huang. This study was, in part, supported by grants NSC97-2628-B-182-001-MY3 from the National Science Council of Taiwan and NHRI-100AI-PDCO-0909111 from the National Health Research Institutes of Taiwan and RA11028 from Department of Medical Research and Development, Show Chwan Memorial Hospital, Taiwan.

\section{Author details}

'Department of Medical Research and Development, Show Chwan Health Care System, Changhua, Taiwan. ${ }^{2}$ Department of Pediatrics, Chang Gung Memorial Hospital-Kaohsiung Medical Center, Chang Gung University College of Medicine, Kaohsiung, Taiwan. ${ }^{3}$ Department of Biological Sciences, National Sun Yat-sen University, Kaohsiung, Taiwan.

Received: 15 May 2012 Accepted: 4 December 2012 Published: 8 December 2012

\section{References}

1. Clarke T: Dengue virus: break-bone fever. Nature 2002, 416(6882):672-674.

2. Thomas SJ, Strickman D, Vaughn DW: Dengue epidemiology: virus epidemiology, ecology, and emergence. Adv Virus Res 2003, 61:235-289. 
3. WHO Expert Committee on Viral Haemorrhagic Fevers: Viral haemorrhagic fevers. Report of a WHO Expert Committee. World Health Organ Tech Rep Ser 1985, 721:5-126.

4. Guzman MG, Halstead SB, Artsob H, Buchy P, Farrar J, Gubler DJ, Hunsperger E, Kroeger A, Margolis HS, Martinez E, et al: Dengue: a continuing global threat. Nat Rev Microbiol 2010, 8(12 Suppl):S7-S16.

5. Rigau-Perez JG, Clark GG, Gubler DJ, Reiter P, Sanders EJ, Vorndam AV: Dengue and dengue haemorrhagic fever. Lancet 1998, 352(9132):971-977.

6. Monath TP: Dengue: the risk to developed and developing countries. Proc Natl Acad Sci USA 1994, 91(7):2395-2400.

7. Butt N, Abbassi A, Munir SM, Ahmad SM, Sheikh QH: Haematological and biochemical indicators for the early diagnosis of dengue viral infection. J Coll Physicians Surg Pak 2008, 18(5):282-285.

8. Nimmannitya S: Clinical manifestations of dengue/dengue haemorrhagic fever. In Monograph on dengue/dengue haemorrhagic fever. Edited by Thongcharoen P. New Delhi: WHO-SEARO; 1993:48-54.

9. Burke DS, Nisalak A, Johnson DE, Scott RM: A prospective study of dengue infections in Bangkok. AmJTrop Med Hyg 1988, 38(1):172-180.

10. Halstead SB, Nimmannitya S, Cohen SN: Observations related to pathogenesis of dengue hemorrhagic fever IV. Relation of disease severity to antibody response and virus recovered. Yale J Biol Med 1970, 42(5):311-328.

11. Lipscomb MF, Masten BJ: Dendritic cells: immune regulators in health and disease. Physiol Rev 2002, 82(1):97-130.

12. Mohamadzadeh M, Luftig R: Dendritic cells: In the forefront of immunopathogenesis and vaccine development - A review. J Immune Based Ther Vaccines 2004, 2(1):1.

13. Sozzani S, Vermi W, Del Prete A, Facchetti F: Trafficking properties of plasmacytoid dendritic cells in health and disease. Trends Immunol 2010, 31(7):270-277

14. Gee K, Guzzo C, Che Mat NF, Ma W, Kumar A: The IL-12 family of cytokines in infection, inflammation and autoimmune disorders. Inflamm Allergy Drug Targets 2009, 8(1):40-52

15. Rajkovic I, Dragicevic A, Vasilijic S, Bozic B, Dzopalic T, Tomic S, Majstorovic I, Vucevic D, Djokic J, Balint B, et al: Differences in T-helper polarizing capability between human monocyte-derived dendritic cells and monocyte-derived Langerhans'-like cells. Immunology 2011 132(2):217-225

16. Yu HR, Chen RF, Hong KC, Bong CN, Lee WI, Kuo HC, Yang KD: IL-12independent Th1 polarization in human mononuclear cells infected with varicella-zoster virus. Eur J Immunol 2005, 35(12):3664-3672.

17. Manca C, Tsenova L, Bergtold A, Freeman S, Tovey M, Musser JM, Barry CE 3rd, Freedman VH, Kaplan G: Virulence of a Mycobacterium tuberculosis clinical isolate in mice is determined by failure to induce Th1 type immunity and is associated with induction of IFN-alpha /beta. Proc Nat/ Acad Sci USA 2001, 98(10):5752-5757.

18. Cousens LP, Peterson R, Hsu S, Dorner A, Altman JD, Ahmed R, Biron CA: Two roads diverged: interferon alpha/beta- and interleukin 12-mediated pathways in promoting $T$ cell interferon gamma responses during viral infection. J Exp Med 1999, 189(8):1315-1328.

19. Kumar H, Kawai T, Akira S: Pathogen recognition by the innate immune system. Int Rev Immunol 2011, 30(1):16-34.

20. Katashiba Y, Miyamoto R, Hyo A, Shimamoto K, Murakami N, Ogata M, Amakawa R, Inaba M, Nomura S, Fukuhara S, et al: Interferon-alpha and interleukin-12 are induced, respectively, by double-stranded DNA and single-stranded RNA in human myeloid dendritic cells. Immunology 2011, 132(2):165-173.

21. Ito T, Amakawa R, Kaisho T, Hemmi H, Tajima K, Uehira K, Ozaki Y, Tomizawa $H$, Akira S, Fukuhara S: Interferon-alpha and interleukin-12 are induced differentially by Toll-like receptor 7 ligands in human blood dendritic cell subsets. J Exp Med 2002, 195(11):1507-1512.

22. Palmer DR, Sun P, Celluzzi C, Bisbing J, Pang S, Sun W, Marovich MA Burgess T: Differential effects of dengue virus on infected and bystander dendritic cells. J Virol 2005, 79(4):2432-2439.

23. Pollara G, Jones M, Handley ME, Rajpopat M, Kwan A, Coffin RS, Foster G, Chain B, Katz DR: Herpes simplex virus type-1-induced activation of myeloid dendritic cells: the roles of virus cell interaction and paracrine type I IFN secretion. J Immunol 2004, 173(6):4108-4119.

24. Ito T, Wang YH, Liu YJ: Plasmacytoid dendritic cell precursors/type I interferon-producing cells sense viral infection by Toll-like receptor (TLR) 7 and TLR9. Springer Semin Immunopathol 2005, 26(3):221-229.
25. Roses RE, Xu S, Xu M, Koldovsky U, Koski G, Czerniecki BJ: Differential production of IL-23 and IL-12 by myeloid-derived dendritic cells in response to TLR agonists. J Immunol 2008, 181(7):5120-5127.

26. Rutella S, Danese S, Leone G: Tolerogenic dendritic cells: cytokine modulation comes of age. Blood 2006, 108(5):1435-1440.

27. Sallusto F, Cella M, Danieli C, Lanzavecchia A: Dendritic cells use macropinocytosis and the mannose receptor to concentrate macromolecules in the major histocompatibility complex class II compartment: downregulation by cytokines and bacterial products. J Exp Med 1995, 182(2):389-400.

28. Jalili A: Dendritic cells and their role in cancer immunotherapy. Iran J Immunol 2007, 4(3):127-144.

29. Larsson $K$, Lindstedt $M$, Borrebaeck CA: Functional and transcriptional profiling of MUTZ-3, a myeloid cell line acting as a model for dendritic cells. Immunology 2006, 117(2):156-166.

30. Chen RF, Yeh WT, Yang MY, Yang KD: A model of the real-time correlation of viral titers with immune reactions in antibody-dependent enhancement of dengue-2 infections. FEMS Immunol Med Microbiol 2001 30(1):1-7.

31. Guzman MG: Global voices of science. Deciphering dengue: the Cuban experience. Science 2005, 309(5740):1495-1497.

32. Yang KD, Yeh WT, Yang MY, Chen RF, Shaio MF: Antibody-dependent enhancement of heterotypic dengue infections involved in suppression of IFNgamma production. J Med Virol 2001, 63(2):150-157.

33. Chen RF, Liu JW, Yeh WT, Wang L, Chang JC, Yu HR, Cheng JT, Yang KD: Altered T helper 1 reaction but not increase of virus load in patients with dengue hemorrhagic fever. FEMS Immunol Med Microbiol 2005, 44(1):43-50.

34. Nagahara $Y$, Nagamori $T$, Tamegai $H$, Hitokuwada $M$, Yoshimi $Y$, Ikekita $M$ Shinomiya T: Inulin stimulates phagocytosis of PMA-treated THP-1 macrophages by involvement of PI3-kinases and MAP kinases. Biofactors 2011, 37(6):447-454.

35. Barilli A, Rotoli BM, Visigalli R, Bussolati O, Gazzola GC, Dall'Asta V: Arginine transport in human monocytic leukemia THP-1 cells during macrophage differentiation. J Leukoc Biol 2011, 90(2):293-303.

36. Maess MB, Sendelbach S, Lorkowski S: Selection of reliable reference genes during THP-1 monocyte differentiation into macrophages. BMC Mol Biol 2010, 11:90.

37. Traore K, Trush MA, George M Jr, Spannhake EW, Anderson W, Asseffa A: Signal transduction of phorbol 12-myristate 13-acetate (PMA)-induced growth inhibition of human monocytic leukemia THP-1 cells is reactive oxygen dependent. Leuk Res 2005, 29(8):863-879.

38. Bremner TA, D'Costa N, Dickson LA, Asseffa A: A decrease in glucose 6-phosphate dehydrogenase activity and mRNA is an early event in phorbol ester-induced differentiation of thp-1 promonocytic leukemia cells. Life Sci 1996, 58(12):1015-1022.

39. Boonnak K, Dambach KM, Donofrio GC, Tassaneetrithep B, Marovich MA: Cell type specificity and host genetic polymorphisms influence antibody-dependent enhancement of dengue virus infection. J Virol 2011, 85(4):1671-1683.

40. Chareonsirisuthigul T, Kalayanarooj S, Ubol S: Dengue virus (DENV) antibody-dependent enhancement of infection upregulates the production of anti-inflammatory cytokines, but suppresses anti-DENV free radical and pro-inflammatory cytokine production, in THP-1 cells. J Gen Virol 2007, 88(Pt 2):365-375.

41. Wang L, Chen RF, Liu JW, Lee IK, Lee CP, Kuo HC, Huang SK, Yang KD: DC-SIGN (CD209) Promoter -336 A/G polymorphism is associated with dengue hemorrhagic fever and correlated to DC-SIGN expression and immune augmentation. PLoS Negl Trop Dis 2011, 5(1):e934

42. Chen RF, Wang L, Cheng JT, Chuang H, Chang JC, Liu JW, Lin IC, Yang KD: Combination of CTLA-4 and TGFbeta1 gene polymorphisms associated with dengue hemorrhagic fever and virus load in a dengue-2 outbreak. Clin Immunol 2009, 131(3):404-409.

43. Wang L, Chen RF, Liu JW, Yu HR, Kuo HC, Yang KD: Implications of dynamic changes among tumor necrosis factor-alpha (TNF-alpha), membrane TNF receptor, and soluble TNF receptor levels in regard to the severity of dengue infection. AmJTrop Med Hyg 2007, 77(2):297-302.

44. Chen RF, Yang KD, Wang L, Liu JW, Chiu CC, Cheng JT: Different clinical and laboratory manifestations between dengue haemorrhagic fever and dengue fever with bleeding tendency. Trans R Soc Trop Med Hyg 2007, 101(11):1106-1113. 
45. Yeh WT, Chen RF, Wang L, Liu JW, Shaio MF, Yang KD: Implications of previous subclinical dengue infection but not virus load in dengue hemorrhagic fever. FEMS Immunol Med Microbiol 2006, 48(1):84-90.

46. Yu HR, Chang JC, Chen RF, Chuang H, Hong KC, Wang L, Yang KD: Different antigens trigger different Th1/Th2 reactions in neonatal mononuclear cells (MNCs) relating to T-bet/GATA-3 expression. J Leukoc Biol 2003, 74(5):952-958.

47. Nudelman G, Ge Y, Hu J, Kumar M, Seto J, Duke JL, Kleinstein SH, Hayot F, Sealfon SC, Wetmur JG: Coregulation mapping based on individual phenotypic variation in response to virus infection. Immunome Res 2010, 6:2.

48. Pang T, Cardosa MJ, Guzman MG: Of cascades and perfect storms: the immunopathogenesis of dengue haemorrhagic fever-dengue shock syndrome (DHF/DSS). Immunol Cell Biol 2007, 85(1):43-45.

49. Friberg H, Bashyam H, Toyosaki-Maeda T, Potts JA, Greenough T, Kalayanarooj S, Gibbons RV, Nisalak A, Srikiatkhachorn A, Green S, et al: Cross-Reactivity and Expansion of Dengue-Specific T cells During Acute Primary and Secondary Infections in Humans. Sci Rep 2011, 1:51.

50. Wahala WM, Silva AM: The human antibody response to dengue virus infection. Viruses 2011, 3(12):2374-2395.

51. Pawitan JA: Dengue virus infection: predictors for severe dengue. Acta Med Indones 2011, 43(2):129-135.

52. Restrepo BN, Ramirez RE, Arboleda M, Alvarez G, Ospina M, Diaz FJ: Serum levels of cytokines in two ethnic groups with dengue virus infection. AmJTrop Med Hyg 2008, 79(5):673-677.

53. Pulendran B: Variegation of the immune response with dendritic cells and pathogen recognition receptors. J Immunol 2005, 174(5):2457-2465.

54. Rovera G, Ferrero D, Pagliardi GL, Vartikar J, Pessano S, Bottero L, Abraham S, Lebman D: Induction of differentiation of human myeloid leukemias by phorbol diesters: phenotypic changes and mode of action. Ann N Y Acad Sci 1982, 397:211-220.

55. Kamiya T, Makino J, Hara H, Inagaki N, Adachi T: Extracellular-superoxide dismutase expression during monocytic differentiation of U937 cells. J Cell Biochem 2011, 112(1):244-255.

56. Daigneault M, Preston JA, Marriott HM, Whyte MK, Dockrell DH: The identification of markers of macrophage differentiation in PMAstimulated THP-1 cells and monocyte-derived macrophages. PLoS One 2010, 5(1):e8668.

doi:10.1186/1471-2334-12-340

Cite this article as: Chen et al:: Induction of IFNa or IL-12 depends on differentiation of THP-1 cells in dengue infections without and with antibody enhancement. BMC Infectious Diseases 2012 12:340.

\section{Submit your next manuscript to BioMed Central and take full advantage of:}

- Convenient online submission

- Thorough peer review

- No space constraints or color figure charges

- Immediate publication on acceptance

- Inclusion in PubMed, CAS, Scopus and Google Scholar

- Research which is freely available for redistribution 